\title{
INSTITUTIONS AT THE INTERFACE OF URBAN PLANNING AND REAL ESTATE
}

\author{
Tom Kauko \\ Independent scholar, Budapest, Hungary \\ e-mail: tom.kauko@yahoo.co.uk
}

\begin{abstract}
While being largely confined to different realms, planning and real estate also have a symbiotic relation. The logic of this relation varies in time and space, which makes the analysis of the balance between the two fields challenging. When we define these actions as institutions, potentially powerful analytic tools become available. This critical literature review examines some of the most relevant of them, in various specific institutional arenas, including the impact of planning on property markets and prices. The aim is to examine the role of institutions at the interface of urban planning and real estate. In other words, to see what kind of institutional effects are identifiable, whenever planning and property interests overlap. The conclusions suggest that a change in the urban fabric is likely to impact the possibility to use a site, and thereby also the value of land and built property.
\end{abstract}

Key words: institutions, planning, property markets, property prices, real estate.

JEL Classification: $R 30, R 31, R 33$.

Citation: Kauko T., 2019, Institutions at the Interface of Urban Planning and Real Estate, Real Estate Management and Valuation, vol. 27, no. 3, pp. 17-30.

DOI: $10.2478 /$ remav-2019-0022

\section{Introduction}

When considering various types of land and built property, markets and planning regulations are both examples of institutions (BALL 1998; WEBSTER 2005; see also KEOGH, D'ARCY 1999, 2000). Specific planning issues can be seen as public institutions; on the other hand, the market for land and built property is usually identifiable as a private institution, but predominantly public cases also exist, for example, land transactions of large authorities such as railway companies. More often than not, these two interests, private and public, collide.

The starting point here is the two way interaction between real estate and planning 1 . While these are interrelated built environment activities, their orientations are traditionally sharply separated fields. Interests in real estate assume strong private property rights and protection of value. Interests in planning assume relatively strong public property rights, revitalization (or just retention) of the community, protection of heritage and environment, and - depending on the type of regime boosting the local economy in the long-term (cf. EvANS 2008). However, those two realms also have a symbiotic relation.

On the one hand, cities do not exist without homes and workplaces for their inhabitants; on the other hand, a well maintained and high quality urban amenity along with the timely provision of buildings and building land will keep property price increases at steady equilibrium rates. Here the difficulty, of course, is to control the feedback process between urban management and assuring market functionality. This deliberation concerns the general limits of planning, and how to balance

\footnotetext{
1 This refers primarily to urban planning, including principles of both spatial and non-spatial (i.e. functional)
} planning. 


\section{$\$$ sciendo}

aesthetic, efficiency, equity and sustainability goals with regard to specific indicators such as density, land market, land value and housing affordability (see EVANS 2008).

In this vein it can also be argued that, for at least last three decades, planning has faced conceptual challenges in increased uncertainty, diversity and incommensurability, and, as a consequence, our "plural world" calls for a "multiple approach" to planning that is different than the one based on seemingly rational linear models of delivery that was apt until the early 1980s (HILLIER 2010; VERSTEEG, HAJER 2010). Planning can be understood in different ways, and traditionally, two perceptions are common: at one extreme, it is seen as an abstract moral code and set of philosophic principles that has a tendency to change in time; at the opposite extreme, it can be evidenced through any pragmatic space-quality allocations in relation to political, social, demographic, environmental and economic parameters. Paradigmatic arguments notwithstanding (see e.g. BALL, JONES 2013), the useful discovery here is that planning can be situated in a real estate relevant, meaningful way via institutional economics (see WEBSTER 2005).

Institutional economics can be applied from several different vantage points, and this is also the case within built environment studies. The essence here is to capture the institutional circumstances when a given project begins. As already noted, both planning and real estate markets can be seen as types of institution - the rules of the game - cultural, political and administrative (cf. BUITELAAR, SEGEREN 2011). These are, in general, understood as being of three types: conventions, norms and formally sanctioned rules. ${ }^{2}$ In this conceptualization, tacit knowledge, that is knowing what is expected "from father to son", is crucial for understanding the differences of these categories (VATN 2005). The differences between the three types of institutions can be seen via this learning process (following SCOTT 1995): (1) Conventions are functional modes of behavior that one mimes when recalling what an authoritarian figure has told. These constitute a cognitive type of institution - taken for granted, including imitation (e.g. behavior when considering property purchase). (2) Norms one follows and often without necessarily having to think back about the original function that triggered such behavior - these social obligations are morally governed (e.g. recycling household waste). (3) Rules one just accepts and follows in order to avoid some sort of likely sanctions, often without speculation of their original function, but rather one's self-interest (e.g. building regulations).

The study presents a critical, structured, analytical review of the literature around the interrelations between planning and real estate. The important methodological aspect herein is to tease out the institutional influence - either formal or informal. To achieve this aim, the effects of government regulation are selected here as general starting point. It needs to be stated that these effects can occur either directly or indirectly when we consider their impact on real estate pricing or development activities. This aspect has traditionally been neglected or treated in an implicit fashion in real estate research. More recent times, however, have witnessed a concern for more explicit treatment as well (cf. ADAMS et al., 2005; KAUKO 2012a, b; HUTCHISON, DisBERRY 2015; THEURILlAT et al., 2015).

A particularly popular institutional real estate perspective focuses on property rights. When looking at how a particular "property rights regime" affects the land development process, Havel (2009) empirically shows how institutions, such as the local government, type of development control and economic rights in land development, affect market processes. Subsequently Havel (2014) also examines how delineation of property rights creates institutional foundations for land markets in transition, which is helpful, considering urban problems such as spatial inequality and polarization, caused by overt emphasis on private property rights. A related school of institutional thought concerns the "property market process", and thus characteristics of the property itself and the process through which it is traded (see KEOGH, D'ARCY 1999, 2000). However, while extremely important problem areas in themselves, the present contribution is not constrained to these two traditions. It rather looks at real estate situations from a more general vantage point in order to offer a conceptual analysis of planning based influences - a debated category of institutions in this context.

The organization of the study is as follows: section 2 deals with general institutions; section 3 with planning and property as institutions; section 4 with the impact of planning on property price and markets; and, finally, section 5 draws conclusions.

\footnotetext{
2 Here, it needs to be noted that institutions are not the same as organizations - the players of the game. Unfortunately, this terminology is often confused in real estate literature. Hence seminal work on the role of institutions in real estate analysis, such as Ball's (1998) review of the specifically British context, were misunderstood by a large portion of the audience.
} 


\section{How to approach institutions - some general suggestions}

\subsection{Background of institutional analysis}

At the core of this theoretical approach is the principle that real evolution happens everywhere. And in any particular "real world" social-economic setting, this is directed by institutions. In social science literature, institutions are commonly categorized into three main types: conventions, norms and formally sanctioned rules (see Fig. 1). Here we note that "institutionalism" - old and new - is a field of study on these objectives, from either economic or social point of view. Below we discuss the innovators and stages in the development of the various subfields of institutionalism. The discussion begins with more general notions of social interaction and administrative behavior, and then picks up institutional factors at the level of constrained decision-making, and eventually - markets.

Bromley: institutions enable not just constrain choices; furthermore, power relations matter as some groups get more protection than others

\begin{tabular}{|c|c|c|c|}
\hline \multirow{3}{*}{$\begin{array}{l}\text { Internalized } \\
\text { conventions }\end{array}$} & $\begin{array}{l}\text { Conventions: Mere } \\
\text { coordination of } \\
\text { complex situations }\end{array}$ & $\begin{array}{l}\text { Norms: } \\
\text { potential } \\
\text { social values }\end{array}$ & $\begin{array}{l}\text { Formally sanctioned rules: } \\
\text { regulate/normalize conflict }\end{array}$ \\
\hline & & & Externalized rules \\
\hline & $\begin{array}{l}\text { 1. Veblen: } \\
\text { habits }\end{array}$ & $\begin{array}{l}\text { 2. Bromley: } \\
\text { the choice } \\
\text { set }\end{array}$ & $\begin{array}{l}\text { 3. North: } \\
\text { constraints }\end{array}$ \\
\hline
\end{tabular}

Richard Scott: integrates all three to a realist interpretation of social constructivism (Vatn propagates)

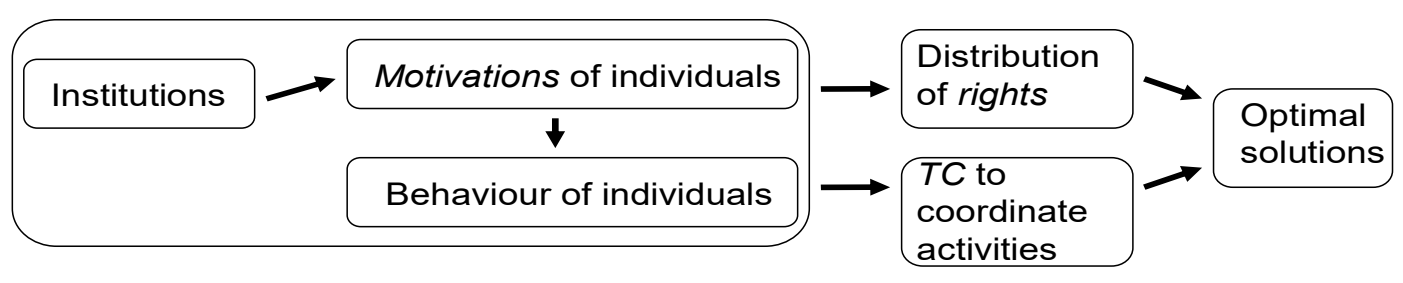

Figure 1. Different ways of approaching institutions. Source: own study.

Institutionalism developed roughly from 1880 to 1950s within various strands of social science. At the turn of the century a "historical German school" argued for the use of historical and comparative research in economics. Subsequently this tradition was transferred to the USA. Early American institutionalists were also influenced by the philosophy of pragmatism. The problem with this work, however, was that much of it degenerated into naive empiricism and mere descriptive analyses of particular topics. There were also parallel traditions in political science and sociology. The former based its approach on moral philosophy and study on political institutions with a normative stance. The latter focused on how institutions interact with individuals, for example professions (SCOTT 1995).

In this context it is usual to separate between old institutional economics (OIE) and new institutional economics (NIE). While space here is not sufficient to outline a comprehensive discussion of each theoretical perspective, a number of core principles about their foci can be noted. Namely, the two approaches take their starting point in different epistemologies. Four methodological points are emphasized by OIE but not accepted by NIE, i.e.: indeterminacy, endogenous preferences, behavioral realism and being against neo-classicist "timeless and placeless assumptions".

What complicates matters is that there is also a need to distinguish between institutional economics (whether OIE or NIE) on one hand, and the "old" and "new" institutionalist traditions in sociology on the other, as these are very different than the ones in economics. This is something that creates confusion unless the definitions of "institution" and "institutional approach" are outlined clearly and consistently, in terms of focus and the level of analysis. It should be observed that new institutionalism within sociology is based on meso-level behavior and purports the cognitive element, thereby being more consistent with OIE than with NIE (SCOTT 1995). While it can be maintained that 
economics and sociology pay attention to different aspects of the analysis, economic OIE approaches and sociology neo-institutionalist approaches exhibit similarity. However, whether these two schools of thought can be approximated, needs to be evaluated on a case-by-case basis.

So what is "new" in institutional sociology corresponds more closely with what is "old" in economics than what is "new" in the latter. According to Richard Scott (1995: 25-26) NIE deals primarily with efficiency of exchange: market, hybrids (franchise, alliance) and hierarchies, whereas OIE deals primarily with customs, laws and politics, i.e., the broader questions in relation to their origins. Actually, in sociology, neo-institutionalism focuses on the effects of cultural belief systems on the environments of organizations rather than intra-organizational processes. NIE and OIE both lend themselves to a more "analytic" and not just "historic" approach. Scott continues his classification of institutionalism as follows using the concept of "the three pillars of institutions" as shown in Table 1.

Table 1

A categorization of institutional approaches

\begin{tabular}{|c|c|c|c|}
\hline $\begin{array}{l}\text { Types } \\
\text { institutions }\end{array}$ & $\begin{array}{l}\text { Regulation (NIE): } \\
\text { coercive; } \\
\text { instrumentality; rules, } \\
\text { laws and sanctions. }\end{array}$ & $\begin{array}{l}\text { Norms } \quad \text { (early } \\
\text { institutional analysts } \\
\text { e.g. Parsons): social } \\
\text { obligation; } \\
\text { normative; morally } \\
\text { governed. }\end{array}$ & $\begin{array}{l}\text { Cognitive (later } \\
\text { institutional } \\
\text { analysts): taken for } \\
\text { granted; imitation; } \\
\text { culturally supported. }\end{array}$ \\
\hline $\begin{array}{l}\text { Defining } \\
\text { questions? }\end{array}$ & $\begin{array}{l}\text { "It is in the actors' self- } \\
\text { interest to conform." } \\
\text { "What are my } \\
\text { interests?" }\end{array}$ & $\begin{array}{l}\text { "Actors conform... } \\
\text { because it is } \\
\text { expected of them." } \\
\text { "What is expected of } \\
\text { me?" }\end{array}$ & $\begin{array}{l}\text { "Actors ... are social } \\
\text { constructions." "Who } \\
\text { are we and what sort } \\
\text { of action makes sense } \\
\text { to us?" }\end{array}$ \\
\hline $\begin{array}{l}\text { Philosophy of } \\
\text { science }\end{array}$ & $\begin{array}{l}\text { Social realism; some } \\
\text { version } \\
\text { rational/public choice. }\end{array}$ & $\begin{array}{l}\text { In between social } \\
\text { realism and social } \\
\text { constructivism. }\end{array}$ & $\begin{array}{l}\text { Social } \\
\text { constructivism; } \\
\text { individuals } \\
\text { collectively construct } \\
\text { the world. }\end{array}$ \\
\hline Carriers & Social structures & $\begin{array}{l}\text { Cultures (organization, } \\
\text { society); routines }\end{array}$ & \\
\hline Levels of analysis & Micro (organization) & $\begin{array}{l}\text { Meso-macro (world } \\
\text { system) }\end{array}$ & \\
\hline
\end{tabular}

Source: own study.

Moving to the urban and neighborhood level, KEIL (2006) asserts that institutions can be of four types: informal, formal, abstract and manifest. This highly corresponds to the more common categorizations (e.g. by Scott above) insofar as we talk about formal regulations, informal norms, and abstract cognitive institutions - but the fourth type, i.e., manifest institutions, would be added as a practical level of institutional influence. As argued by VATN (2005), the role of tacit knowledge is important in this categorization. When knowing what is expected from "father to son", decision makers know what to expect from each other.

Scott does not recommend squeezing all institutional approaches into a single and same model, but instead suggests recognizing differences between them in relation to assumptions and emphasis. BROMLEY (2008a), on the other hand, mixes many (perhaps too many) intellectual or philosophical traditions in search of a new choice theory. He advocates OIE over NIE; social relativism ahead of realism; the experimental tradition of behavioral research - i.e. the "Tversky and Kahneman tradition'"- on losses; and also evolutionary dynamics. His main idea is how to use this "choice theory" for public policy. The possible weakness of this analysis, however, is that Bromley emphasizes public policy - it is unclear why public policy should be trusted, no matter how democratic and enlightened policymakers in power are.

Elsewhere, BROMLEY (2008b) argues that our ability is insufficient to grasp the world in its completeness and, therefore, we must limit ourselves to a search for a reduced space of reasonable choices in the world "as it appears to be", instead of rational/optimal choices. Here too his aim is to 
design an alternative theory of human action to be used subsequently for public policy, but his approach is more pragmatic than those presented above. Bromley argues that the world is indeterminate, and that our decision-making is inconsistent, but that, all the same, we have ways of dealing with the confines of the world as it appears to be.

VATN (2005) points out that, when society modernizes, these processes become more complex, but the logic is the same: institutional man is championed over economic man. Humans both influence and are influenced by institutions, and the success of humans is contributed to our ability to internalize and reproduce this system of institutions to such an extent that we can create new institutions even in conflict situations. According to Karl POLANYI (1968), markets are one way, among others, for society to operate. What he referred to as Market Society arose only because the state had laid the foundations for it. Namely, state and capital had the same interests. When society changed, the economic system changed too, though this required a strong role of the state.

\subsection{Transaction costs}

Transaction costs (TCs) include information costs, search costs, power asymmetries and government intervention. It can be argued that transaction costs may not lead to immediate gain: for example, should one attend conferences even if there are obvious transaction costs and this is probably never profitable in a strict rational sense? We go to conferences to learn and socialize, although it is expensive and time-consuming. When do we stop - when we have learnt enough? What is the optimal time spent? Here, we may wonder when to stop looking for new information in the face of increasing time and financial costs. We observe that, because of uncertainty and bounded rationality, instead of optimizing (i.e. continuing to search until the costs exceed benefits), most people apply H. A. Simon's criterion of satisficing (i.e. to seek a satisfactory rather than optimum outcome). ${ }^{3}$

In modern markets economic transactions indeed constitute a separate sphere. However, here also one can argue that the logic is the same as that postulated above: Institutional man is then championed over economic man: humans both influence and are influenced by institutions. In other words, institutional man is a near universal concept: even Robinson Crusoe was a product of his habits and the norms of western culture, as VATN (2005) so wittily points out. Another simple anecdote (also presented by VATN) is the meal as an institution: first, we create it, perhaps due to a discovery of a simple maneuver to rationalize everyday practices; then our children take it for granted and follow, and eventually reproduce it. From this we see the success of humans: we are able to internalize and reproduce this system of institutions, and even in conflict situations, we can create new institutions. Of course, when society modernizes, these processes become more complex, but the logic remains the same. This is an example of an evolutionary process. However, the standard application area of Neoclassical Economics (NCE) fails to recognize this and continues to stick to the following assumptions:

- no transaction costs,

- no information costs,

- private property rights for all goods are exchanged in competitive markets.

When we consider the last of the three assumptions, we note an inconsistent state of affairs in the NCE model. Namely, the coercion of the rules is assumed to take place by police, courts, inspection of quality control or other means, but it would "just happen" automatically. The corresponding logic of NIE is not too different from this - in fact, a second-level optimization problem: how to set "optimal" institutional constraints.

MOREOVER, VATN (2005) makes a distinction between two views on transaction costs: one, Coase's original view that externalities are a rational result of high TCs, and that, therefore, TCs ought to be minimized; and two, those so-called "Hyper-Coasians" who, unlike Coase himself, claim that TC $=0$.

\subsection{Synthesis of general institutional approaches}

What elements from the discussion above would be useful for our conceptualization of the effect of planning on real estate markets and prices? Here, a critical view is necessary. The way society is structured by institutions has implications on individual and group behavior, and on how markets evolve in relation to TCs. We can compare the basic ideas of each insitutionalist with regard to their

\footnotetext{
${ }^{3}$ By no means do all share this attitude to research. Ongoing research suggests that Optimization models for land
} use management may be on their way back - that is to say, if they had ever in fact disappeared. 


\section{S sciendo}

key claims and arguments as follows:

- Veblen and Polanyi can be seen as fathers of OIE, whereas North and Coase can be seen as their NIE counterparts.

- Scott and Vatn offer a realist interpretation of social constructionism.

- Keil extends the analysis to the practical level, and in relation to the urban setting.

- Bromley's variant of OIE focuses on constrained choices at the moment of decision making.

- Simon relaxes the choice model to accept the notion of "satisfactory" human behavior.

Thus, the last three streams of thought can be taken into consideration in further discussions on planning and property relevant institutions. This, after all, is about why and how actors with various backgrounds make decisions with consequences for the built environment. Against this backdrop, one can definitely pick up several planning and real estate issues at stake in the urban environment.

\section{Planning and property development as institutions}

Following the outline of general institutional approaches above, institutions are potentially identifiable at the level of society, choice and market. In the context of a built environment, institutions can have a variety of more specific meanings within both private and public domains (BALL 1998). In search for such meaningful tendencies, RUMING (2010) analyses developer typologies in urban renewal, based on experiences from Sydney, Australia. He finds that informal institutional arrangements are vital in the negotiations. While formal rules based on law are the primary means of resolving conflict, informal relations based on local knowledge and associations can supplement the aforementioned category of institutions. Here the "like mindedness" of developers and planners is an important aspect to consider. He also notes that informal arrangements relate to the type of developer, in determining the efficiency of development. The smaller the developer, the more important trust and, by implication, informality; the larger the developer, the more important legal underpinnings become. The key here is that if more formal institutions are favored, small/medium developers are at disadvantage, RUMING purports.

The research on property development using institutional approaches, OIE in particular, is evidently growing. HENNEBERRY and PARRIS (2013) propose a theoretical framework using project ecologies. This would be consistent with OIE (and also support RUMING above) in the sense that the role of trust is the key to the analysis. Furthermore the target of such an institutional analysis is to gain an understanding of details related to the organization of a project, the culture of a developer and the institutional context in which it acted (p. 237). Their main finding is that planners can also influence developers, not only vice versa. HENNEBERRY and PARRIS concluded that, at the time, relatively little was still known about "perspectives, actions and strategies of property developers", and that, in the existing body of research, the "under-socialized" treatment was a concern.

Focusing on institutions in the context of spatial planning and land development interaction, VAN RIJ and KORTHALS AlteS (2010) note that, while separation of the two functions ensures a high level of ethical behavior, links between these two can be made more effective. They argue that the cultural differences between "visionary" planners and "practical" developers could be overcome by a revision of institutions. The result would be more effective interaction; serving as an example is the Dutch mechanism of financing unprofitable developments from profitable developments (i.e. cross-subsidystrategy) $)^{4}$.

LEFFERS (2017) examines how new land-use institutions emerge and are shaped, using the case of the Toronto region, Canada. He argues that the actions and ideas of developers influence the knowledge and practices of land-users, which, consequently, has implications for land-use, planning and property. Therefore, property law is not seen as an objective system of rules, nor a singular concept to protect property rights, but rather as an institution. Recognizing this relation, Leffers propose a three way model of interaction among developers, social movements and politicians. He notes that property rights constitute far more than a simplistic view of developers; in the end, someone has to grant those property rights - in principle, through the democratic process. In the analytical sense, a model where developers have specific relations to municipal planners and politicians fits the notion of "in-between approach" to real estate and planning. (Institutional analysis is often about "in-between" approaches.)

\footnotetext{
${ }^{4}$ In economic land-use studies, this Dutch innovation is sometimes also referred to as the Red-for-Blue policy or mechanism (see Goetgeluk et al., 2005).
} 
PAYNE (2013) analyzes house-builder behavior in relation to the interactions between the state and market. Examining the UK experience during the period 2000-2020, she relates institutional change to the industry's reluctance to change. For the industry, one of the uncertainties here is that institutional change in speculative housebuilding may or may not occur, and this is significantly dependent on the roles of organizations (by definition not the same as institutions). What matters here is whether emerging companies can establish themselves considering existing business models and volatile institutional contexts. She concludes that, to understand these processes, we need better linking of the actions of planners and the real estate industry.

Different places generate different institutional frameworks, depending on their planning traditions. Historical institutionalism is well-placed to explain variation among places in this respect. This tradition emerged in the 1970s in political science and sociology, when it was proposed that institutions structure the opportunities and constraints for individual and collaborative actors. In explaining planning culture, it recognizes a distinction between "organizational culture" and "societal culture" - it is about how professional norms and practices function in the context of spatial development. At the same time, the susceptibility of planning cultures varies depending on institutional circumstances. For example, the case of Portland, Oregon shows that nurturing support coalitions (i.e. how existing property-oriented institutions are continued or changed) matter for the framing of the planning issues at stake. Therefore, an institutional approach has greater explanatory power than a pure cultural approach (TAYLOR 2013).

TAYLOR (2013) sees the cultural explanation connected to the institutional analysis of how planning and real estate markets interact. He notes that private interests - notably existing property owners are likely to support the continuation of institutions and practices that increase the predictability in investments in property and, by implication, development controls and other measures that protect property value and neighborhood character in established areas. This idea fits the notion of a feedback mechanism between planning and market clearing as discussed by this author in earlier papers (see KAUKO 2003a, b).

The broader cultural, political and administrative issues are not to be sidestepped whenever we look at the institutional analysis of land-use and real estate markets. SHATKIN (2016) uses the new term real estate turn for when state actors capitalize on rapid land value increases occurring due to periurbanization in Asia. The idea here is that, for governments, the enormous land price increases create new opportunities due to the improvement of infrastructure and amenities, as well as new challenges because of the distortion of existing settlements.

The extent to which institutional factors hinder the delivery of property development became a topical issue already before the global financial and economic crisis in 2007-08 (see KAUKO 2003a,b; ADAMS et al. 2005). However, HUTCHISON and DISBERRY (2015) showed that the real constraint for housing development on brownfield land is more about the market than about planning, as post crisis evidence from their study area, Nottingham, UK, suggests. In any case, the two concepts: market and planning, are part of the same real estate reality.

Institutions are also considered stabilizing factors, and not just undesirable market friction, resulting, as argued, in the strictest transaction cost approach; as such, the new institutionalist key argument is "the lesser the transaction costs, the better" (see, e.g., JAFFE 1996). Here, however, the argument is different: in order to reduce the uncertainty prevailing in the development process, we need to have stabilizing institutions as well - for instance the role of the planning system to outline the areas where building is permitted - not restricted. Furthermore, as the market is not a neutral allocator of resources, there are always some stakeholders who benefit more than others, and also the dynamic nature of the system makes deterministic conclusions difficult.

Traditionally the land economic analysis has applied the Ricardian land rent and neoclassical equilibrium frameworks on the issue of residential land value and house prices. This mode of analysis, however, is arguably not well equipped to deal with issues such as planning and development processes, which often are rather discontinuous and indeterminate in nature. Here, we introduce additional factors: the role of costs and the complexity of actor networks (JAFFE 1996)

In a critical examination of the institutional economics approach to property research, GUY and HENNEBERRY (2000) concluded that we need a relational approach to deal with cultures of market participants. Their specific case pertained to how economic and social goals can be fitted together to promote urban development. At the time, this kind of alternative methodological and theoretical 
approach was needed, as the call was for a better understanding of what really goes on - the wider context of the development process. ${ }^{5}$

BUITELAAR and SEGEREN (2011) assert that institutional economics offers a more realistic view of urban structures and land than neoclassical economics, and in addition to this, it also fits particular circumstances better. They analyze how property rights influence urban morphology, built structures and land in two ways: directly, via incorporating existing land uses, and indirectly, via physical measures in the Netherlands. They conclude that property rights and physical development are connected via various agency relations: a change in the plan also means a change in value, and property rights significantly influence the development of an urban area (cf. HAVEL, 2009, 2014).

To make an interim brief synthesis in line with the general discussion in the previous section, when it comes to detecting institutions in planning and property development, we can distinguish at least three broad categories of institutional influence from the discussion above:

- negotiation, trust and other informal issues that stretch beyond the existence of property rights (e.g. Ruming, Leffers)

- place-boundedness of choices (e.g. Taylor, Shatkin)

- costs and complex actor networks as market influences (e.g. Jaffe, Havel).

The review hitherto shows that the main topics of institutional economics in this context relate to development and building activity. In other words, the provision of buildings and real estate is at the core of any institutional economic analysis of urban environments. Institutional economics furthermore offers possibilities to use urban real estate markets for poverty alleviation, thus not only to improve markets, but also to look after the urban poor (MOOYA 2011). This would follow a more comprehensive framework by Elinor Ostrom rather than the narrower view on securing property rights put forward by Hernan de Soto. Ostrom's idea is aimed at securing property rights, providing physical infrastructure and focusing on how culture determines economic outcomes.

In line with what has been discussed so far, the next discussion is turned towards the issue of how this balance between the two ideals: real estate and planning, is to be addressed. The next discussion is based more on conceptualizations founded on OIE than those on NIE or economics of property rights. This is because the latter strands of analysis have been covered elsewhere (see JAFFE 1996; NEEDHAM, DE KAM 2004; BUITELAAR, SEGEREN, 2011). In this analysis, the real estate oriented ideal is concerned with preserving values and protecting property rights when there is a lack of trust towards any planning measures. The planning side, in turn, is preoccupied with protecting everyman's rights and developing larger areas, and does not, therefore, necessarily understand (or want to understand) the problem of land and property owners who are affected by the actions of planners. How exactly the relation between real estate market and planning plays out depends on how public bodies, such as the parliament and the local government, create specific planning regulations; this is furthermore contingent on past experiences and problems of relations with society at large (i.e. path-dependence) ${ }^{6}$

\section{Planning as an institutional aspect of property markets and prices}

Planning has two particular effects on property and housing market and price: one, it may affect the total supply within a country, either positively, or negatively; two, it may affect the supply within certain submarkets and locations (e.g. HEALEY 1998); apart from that effect, there is an amenity effect (demand side premium for popular submarkets or locations) and an effect stemming from possible oligopolistic outcomes (see, e.g., MONK, WHITEHEAD 1996).

Many sources of controversy and agreement exist when it comes to defining the balance of public and private rights to built property (see e.g. WALSH 2017). PEEL and LLOYD (2007) note that tensions arise because of two different requirements: on one hand, the need to include the public, and on the other - market efficiency and guaranteed private property rights (cf. TIESDELL, ALLMENDINGER 2005; MONK, WHITEHEAd 1999; HeAley 1991; WEBSTER 2005). The latter issue is at the core of real estate industry participants' concern. What is the apt use for a plot of developable land? Here different worldviews tend to collide, whenever planning policy is insensitive to property markets (e.g. CHESHIRE 2013).

\footnotetext{
5 Since then however we have seen more of the kind of blended social-economic approaches involving institutional influences, such as a number of contributions by this author (e.g. KAUKO, 2012a,b).

${ }^{6} \mathrm{I}$ am indebted to one of the referees for making this point.
} 
The residential side is often brought in as a particularly illustrative case in point, due to the several microeconomic issues at stake (cf. D'AMATO, KAUKO 2008; DUNSE 2013). Typically the question regards whether a housing development is feasible, or even possible (one might add: at a given point in space-time)? BRAMLEY (2013), for instance, argues that, in the UK, the way the connections between the housing market and the planning system were approached changed after the Barker Review 2004, when housing affordability problems resulting from land use constraints were being targeted at a government level. BRAMLEY also places this shift in the recent history of planning for housing in this country, by outlining three different stages: (1) When more housing was built (postwar period until the early 1970s); (2) When housing was off the agenda (1975-2004); and (3) When Barker review brought it back, and subsequently introduced the economic feedback mechanism to the model. In this development, he furthermore defines a speculative fourth stage connected to the Conservative-led Coalition Government's localization agenda after 2010. So, after the Barker review managed to bring economic models to the center of the system, the post-2010 regime further complicated the issue, as sub-regional and local models were now advocated more than before (See also DUNSE 2013).

When HINCKS and colleagues (2013) discuss the relations between housing markets and planning in the UK, they point out that, in any such analyses, also institutional and behavioral influences need to be accounted for. They conclude that planning is about steering and stimulating markets rather than constraining them. ${ }^{7}$ While most of this research tradition is built from US- and UK-based findings, similar evidence about land regulation increasing house prices has also been verified in other parts of the world (see e.g. LAURIDSEN et al. 2013, on Copenhagen, Denmark).

There are also arenas where real estate market and public policy concerns interact in a natural way. Urban renewal and regeneration is one of them. In a seminal paper on the evaluation of urban regeneration initiatives, ADAIR and colleagues (2003) examined factors of performance evaluation with regard to rental growth, capital growth and institutions. The issue much concerned the private sector investment - or rather the lack of it - in urban regeneration areas. The traditional bias against such areas, even in big investment portfolios, is a consequence of misconceptions, i.e.: high riskiness and the lack of compensating returns, and these misconceptions tend to be perpetuated due to the lack of data on these areas, ADAIR and colleagues argue.

ADAIR and colleagues find that risk is not significantly different in relation to the market as a whole, and, in some cases even lower. Thus, a weak level of transparency leads to potentially incorrect perceptions of these areas, and significant opportunities exist for private sector investment. (Here retail property was found to perform particularly well.) Therefore, if urban regeneration areas are, in reality, not so different from other areas in terms of their property market performance, the underinvestment in these areas could be reverted. The authors note that, apart from increasing the opportunities for private sector investors, urban managers can also use property market performance in urban regeneration areas as an urban competitiveness strategy.

THEURILLAT and colleagues (2015) explore the multitude of possibilities opened up by an approach inspired by the historian Fernand Braudel (1902-85). ${ }^{8}$ In this conceptualization, planning and real estate are interlinked, with further links to land value and the financial system. There are several layers here, namely market trends in relation to property type, players in relation to institutions, territorial situations, and temporalities. The findings here deconstruct market activity into local and global, and day-to-day and long term components. ${ }^{9}$

When considering Braudel's approach, the broader position here is agreeable. This is indeed about quantifiable evidence rather than ideological stances. On the planning side, the novelty lies in methods to reconcile very different kinds of interests together under a "smallest denominator" institutional design. On the real estate side, the interesting cases with institutional interference represent two main types: one is about how "hard" institutions - so: formal rules and regulations (referring to Fig. 1 earlier) - are placed to impact the formation of real estate prices via market or nonmarket actions. The other is about the "soft" institutions - so value factors that are not codified. This latter aspect brings us towards the role of the informal economy in this context - while regulations

\footnotetext{
7 At least these authors, who by and large represent housing and land economics traditions, declare that they 'think that planning can work'.

8 Braudel's geo-historical method of course is much praised as it opposed political ideologies and relied on detailed quantification instead.

${ }^{9}$ This analysis resonates with this author's own work on urban regeneration.
} 
ideally define property rights, this relationship is not optimal, as real estate actors try to avoid the regulations whenever possible (KUCHARSKA-STASIAK, 2016).

When looking at the interaction between planning and house prices at that kind of smaller geographical scale, LIU and ROBERTS (2013) bring counter-urbanization to the mix. Based on an analysis of the Aberdeen Housing Market Area in 1984-2010, they show how migration and price differences relate to three segments: city, suburb and accessible rural areas. In their theoretically informed analysis, separate price indices were estimated for the three. The results show how city and suburb react differently than accessible rural areas in terms of associations between recorded movements of the population and prices across this urban area. LIU and ROBERTS concluded that both counter-urbanization and planning frameworks have a tendency to influence the price of housing, and that the latter also influences the former. These authors also concluded that we need to plan and coordinate land-use change across functional areas. Indeed, planning for new housing areas (in city, suburb or accessible countryside) can enable prices to stay in relative equilibrium and even dampen price inflation, and thereby avoid situations with over-demand and under-supply (see KAUKO 2003,a,b; D'AMATO, KAUKO 2008).

When looking at possible interactions between government and markets in a built environment context, no effect has been explored more thoroughly than the effect of land use planning or other kinds of regulation on property prices (including rental prices). Literature suggests that planning may either decrease or raise property values because of more efficient land use (yet debated effect); on the other hand, most of the literature concentrates on the effect of planning on restricting building supply and thereby increasing prices (more certain effect). Of the two effects, the latter is already wellcovered in the literature, at least since 1980s, so we follow the former line of reasoning - a more debated effect here (see e.g. POGODZINSKY, SASS 1990, 1991; KAUKO 2003,a,b).

In a traditional mode of urban land and real estate economic analysis, building regulation and modification of permitted area density has theoretically justifiable (and sometimes rather straightforward) price effects (see BALL, JONES 2013; CHESHIRE 2013). Land price would always increase with increased building efficiency of the site, as long as demand is projected and a realization of the additional floor-space appears likely. For the total price of the property, in turn, the same is true in so far as dealing with a rather normal market case, thus bulk property, where increased floor-space is seen as something that increases market value. However, trophy property comprises a special case, say for example, a cultural heritage building with antiquarian value where the entire attractiveness depends on the authenticity of the built structures. As long as prestige generates a positive price effect that outweighs the negative ones caused by limitations and restrictions on use, a price increase is sometimes verifiable for such property types - here old cities offer particularly good cases (see ANGJELLARI-DAJCI, CEBULA 2016). ${ }^{10}$ Lastly, here is also a logical effect on unit prices; when realized, the increased floor-space reduces the price per square-meter following the law of diminishing marginal returns. In principle, all these effects are observable and modelled as linear or curvilinear relationships (see DuNSE et al. 2013).

In contrast, for "old institutionalists", the main economic problem to investigate is how to understand the organization and control, and other background factors, of the economic system power relations are the driving force behind this. The planning system in itself - and seen from the real estate perspective - is an example of power relations. ${ }^{11}$ The planning system is therefore an example of an institution. In the UK, for instance, this system designates which land is to be developed and gives market power to landowners (under normal trading conditions); this enables them to extract the surplus (i.e. uplift in value from agricultural use) from development. If controls were reduced, market power would be increasingly transferred to developers, because they would subsequently "shop around" for the best deal in a situation where the original landowners would be unable to lift the value too much from its value in its previous use. It could be argued, in this case, that the impact on property prices would be small in the short run, as prices are determined by other factors, most notably the rent or price of the end product (see WESTON 2003; CROOK, MONK 2011). However, in the long run, the influence is indeed identifiable as the new stock with time accumulates into existing stock (see MONK et al. 1991).

\footnotetext{
10 This could also be about absolute top-location bling addresses such as Savile Row, Mayfair, London.

${ }_{11}$ This applies to circumstances where the planning system involves land use zoning (the USA) or less deterministic procedures of development control (in the UK).
} 
Another good example of an institution is the way in which property prices (both new and preowned) are set. Property developers, builders and real estate agents have recognizable systems (i.e. the institution) of pricing property for sale. In all cases, these are done "administratively"'; for example, for new house-builders it is at board level based on sales or enquiry levels and other factors such as labor and land availability. For real estate agents this is done by comparison with sales of similar properties in the area, but it is also dependent on factors such as the business model of the company and property-owner priorities.

According to ROULAC (2007), government regulations can have both positive and negative influences on the utility, beauty and brand of a given property - and, by implication, also its value. Roulac's key point is that ".. non-market considerations, implemented through various government agencies, can contribute to enhancing brand, beauty and utility for a property interest - or, contrarily, suppress the brand, beauty and utility of a property interest" (p. 434).

The indirect effects also manifest themselves in different ways. To give an example, using data from the new built housing market in Warsaw, ŁASZEK and colleagues (2016) confirm two hypotheses. First, monopoly developers can generate higher prices than what the computed hedonic prices (i.e. quality-adjusted property values) would be. Second, they can also differentiate prices according to the distantness of clients so that those who are from farther afield pay more than local buyers. These authors see, correctly, the developer company as a price maker rather than a price taker, and, as a consequence, as an actor with "monopolistic power" and a "tendency to keep prices high", as well as "propensity to produce excessive supply" (p. 2). So the issue here concerns monopoly power of government-like big market players in the real estate activity in an area; for example, in the case of developer produced units, price levels can sometimes be set artificially high (see ŁASZEK et al. 2016).

Another kind of monopoly situation: the landowners' and developers' spatial monopoly, is wellknown. Some argue that the above notion of the public sector as a monopolist land owner and similar role pales in comparison to the landowner/developer who always has spatial monopoly powers to set the price. In any case, the ability to develop is always a negotiation over a bundle of property rights in which private interests are always listed, most obviously at the point of seeking planning permission. Here the rights of private actors are always circumscribed and the planning function has wider and longer term interests than private sector interests. Hence, the focus on negotiation over, for instance, planning gain and betterment, ${ }^{12}$ Thus both normal situations as well as monopoly-like situations illustrate the arguments of development and use of real estate or land.

It is important to see that, even though all possible aspects are considered, still planning causes price implications one cannot foresee. It should, therefore, be noted that none of the approaches be considered superior to the others in a general sense. The validity depends on the problem setting and target of analysis, as well as the temporal and spatial context we are involved in.

The discussion highlights the ways in which planning, in one form or another, has an omnipresent influence on the development of markets and prices of built property. In short, the argument that planning tends to have market consequences, and more indirectly, also price implications, in one direction or another, is proven to be valid, considering the studies from last two or three decades reviewed above. In principle, this outcome may have a further feedback effect on planning measures such as development control and land use regulation, in so far as their adjustment can be decided based on economic indicators, such as prices and markets alone. In the longer run we may then refer to an adjusted effect, identifiable from time-series data. Obviously, the precise nature and extent of this effect varies, depending on the particular circumstances. And this interaction is what, in real estate analysis, mainstream and otherwise, can be considered an "institutional effect" or the "role of institutions".

\section{Conclusions}

In general terms, institutions direct the society we life in, the individual and group based choices we make, and the markets we transact in. Specifically, in built environment context, the relevant institutions comprise planning on one hand and property development on the other. And in this reality, planning does effect markets and prices of building land, offices, housing and so forth. These three condensed messages refer to Section 2-4 above.

\footnotetext{
12 I am indebted to a referee of an earlier submission of this paper for making this point.
} 
The discussion has identified a clear issue to be addressed by built environment scholars. This issue concerns the balance of real estate and planning in a given situation. How this balance is set depends on the relevant institutions. These may be based on either planning or real estate principles; they also may be either "hard" and formal, or "soft" and informal, in the way discussed. We should bear in mind that why certain institutions are set depends on the broader drivers of real estate and planning: namely, their scientific, legal and practical justifications.

In a generic sense, amidst all the deliberation of respective merits of each discipline, it is important to realize that planning, like the market, is an institution and thereby related to change. And this change can be for the good or worse of those affected by it. Change in nearby amenities - and the urban fabric in a general sense - is likely to impact the possibility to use a site, and thereby also the value of land and built property. To predict this is not exact science, however.

Realistically speaking, social engineering of one element or another here is likely to fail, at least in the longer term. It can reasonably be argued that neither planning nor real estate oriented thinking alone is capable of setting the tone for a favorable evolutionary path. To find synergy is, however, elusive in this context. At a practical level, the problem is that opportunities for collaboration between public and private actors are rarely taken seriously and optimized. Given unavoidable changes in local power-balances and global fashion trends, this is a perennial issue, of course.

\section{Acknowledgements}

The Editor and two anonymous referees deserve thanks for helping me improve the paper to its final form. The same applies to all the helpful colleagues who assisted me in writing this paper (you know who you are).

\section{References}

Adair A., Berry J., MCGReal S., PoON J., HutChison N., WATKINS C., GiBB K., 2003, Benchmarking urban regeneration, RICS Foundation, London, England.

Adams D., Dunse N., White M., 2005, Conceptualising State-Market Relations in Land and Property: The Growth of Institutionalism - Extension or Challenge to Mainstream Economics? In: Adams, D., Watkins, C. and White, M. (Eds.): Planning, Public Policy \& Property Markets, pp. 37-55. Oxford: Blackwell Publishing.

ANGJELLARI-DAJCI F., CEBUla R.J., 2016, The impact of historic district designation on the prices of singlefamily homes in the oldest city in the United States, St. Augustine, Florida, Journal of Property Research, 33(1), 64-96.

BALL M., 1998, Institutions in British Property Research: A Review. Urban Studies, 35(9), 1501-1517.

BALL M., JONES C., 2013, Introduction to Special Issue, Journal of Property Research, 30(3), 167-169.

BRAMLEY G., 2013, Housing market models and planning Town Planning Review, 84(11), 9-35.

Bromley D.W., 2008a, Beyond Market Failure: Volitional Pragmatism as a New Theory of Public Policy, Economia Politica, XXV(2), pp. 219-241.

BROMLEY D.W., 2008b, Volitional pragmatism, Ecological Economics, 68, 1-13.

BuitelaAR E., Segeren A., 2011, Urban Structures and Land. The Morphological Effects of Dealing with Property Rights, Housing Studies, 26(5), 661-679.

CHESHIRE P.C., 2013, Land market regulation: market versus policy failures, Journal of Property Research, 30(3), 170-188.

CrooK A.D., MonK S., 2011, Planning gains, providing homes, Housing Studies, 26(7-8), 997-1018.

D'AMATO M., KAUKO T., 2008, Hedonic indexes on residential rents in the real estate market of Bari: a contribution to urban planning, In Miller, D., Khakee, A., Hull, A. and Woltjer, J. (Eds.): New Principles in Planning Evaluation, Ashgate, Aldershot, pp. 143-165.

Dunse N., Thanos S., BRAMley G., 2013, Planning policy, housing density and consumer preferences, Journal of Property Research, 30(3), 221-238.

EvaNs A.W., 2008, Economics and land use planning, Online edition. John Wiley \& Sons.

Goetgeluk R., Kauko T., Priemus H., 2005, Can Red Pay for Blue? Methods to Estimate the Added Value of Water in Residential Environments, Journal of Environmental Management and Planning, 48(1), 103120.

Guy S., Henneberry J., 2000, Understanding Urban Development Processes: Integrating the Economic and the Social in Property Research, Urban Studies, 37(13), 2399-2416.

HAVEL M.B., 2009, Property rights regime in land development-Analysis of the influence of institutions on 
land development in terms of the property rights theory, Doctoral dissertation. HUT, Faculty of Engineering and Architecture, Department of Surveying. Available online at https://aaltodoc.aalto.fi/bitstream/handle/123456789/13437/isbn9789526036717.pdf?sequence=1 \&isAllowed=y [accessed 5 March, 2019].

HAVEL M.B., 2014, Delineation of property rights as institutional foundations for urban land markets in transition, Land Use Policy, 38, 615-626.

HeAley P., 1991, Models of the development process; a review, Journal of Property Research, 8, 219-238.

HEALEY P., 1998, Regulating property development and the capacity of the development industry, Journal of Property Research, 15 (3), 211-227.

HENNEBERRY J., PARRIS S., 2013, The embedded developer: using project ecologies to analyse local property development networks, Town Planning Review, 84(2), 227-249.

HiLlier J., 2010, Introduction, In J. Hillier and P. Healey (Eds): The Ashgate Research Companion to Planning Theory: Conceptual Challenges for Spatial Planning, Ashgate, Farnham, pp. 1-34.

HinCKS S., LeISHMAN CH., WATKINS C., 2013, Introduction. Planning and housing: concepts, policy instruments and market analysis, Town Planning Review, 84(2), 1-7.

HUTCHISON N., DISBERRY A., 2015, Market forces or institutional factors: what hinders housing development on brownfield land? Journal of European Real Estate Research, 8(3), 285-304.

JAfFE A.J., 1996, On the Role of Transaction Costs and Property Rights in Housing Markets, Housing Studies, 11(3), 425-434.

KAUKO T., 2003a, Planning processes, development potential and house prices: contesting positive and normative argumentation. Focus article. Housing, Theory and Society, 20(3), 113-126.

KAUKO T., 2003b, The Importance of the Context and the Level of Analysis. Author's response, Focus article, Housing, Theory and Society, 20(3), 134-136.

KAUKO T., 2012a, Recreating residential property values in the inner city - an adapted 'old' institutional approach, Journal of Property Research, 29(2), 153-176.

KAUKO T., 2012b, An institutional analysis of property development, good governance and urban sustainability. European Planning Studies, 20(12), 2053-2071.

KeIL A., 2006, New Urban Governance Processes on the Level of Neighbourhoods, European Planning Studies, 14(3), 335-364.

KEOGH G., D'ARCY E., 1999, Property market efficiency: an institutional economics perspective, Urban Studies, 36(13), 2401-2414.

KeOGH G., D'ARCY, É., 2000, Graaskamp, institutional economics, and the real estate market, In Essays in Honor of James A. Graaskamp: Ten Years After, Springer, Boston, MA, pp. 385-409.

KUCHARSKA-STASIAK E., 2016, Grey zone in the Real estate market, Real Estate Management and Valuation, 24(3), 83-92.

ŁasZeK J., OlsZEWSKI K., WASZCZUK J., 2016, Monopolistic Competition and Price Discrimination as a Development Company Strategy in the Primary Housing Market, Critical Housing Analysis, 3(2), 1-12.

LAURIDSEN J., NANNERUP N., SKAK M., 2013, House prices and land regulation in the Copenhagen area, Journal of Property Research, 30(3), 205-220.

LEFFERS D., 2017, Real estate developers' influence of land use legislation in the Toronto region: An institutionalist investigation of developers, land conflict and property law, Urban Studies, 9 November, 117.

LIU N., ROBERTS D., 2013, Counter-urbanisation, planning and house prices: an analysis of the Aberdeen Housing Market Area, 1984-2010, Town Planning Review, 84(1), 81-105.

MONK S., WHITEHEAD C.M.E., 1999, Evaluating the Economic Impact of Planning Controls in the United Kingdom: Some Implications for Housing, Land Economics, 75 (1), 74-93.

MONK S., PeARCE B., WhitehEAD C., 1991, Planning, land supply and house prices - a literature review, Land Economy Monograph 21, University of Cambridge.

MoOYA M.M., 2011, Making urban real estate markets work for the poor: Theory, policy and practice, Cities, $28,238-244$.

NeEdHAm B., De KAM G., 2004, Understanding How Land is Exchanged: Co-ordination Mechanisms and Transaction Costs, Urban Studies, 41(10), September, 2061-2076.

PAYNE S., 2013, Pioneers, pragmatists and sceptics: speculative housebuilders and brownfield development in the early twenty-first century, Town Planning Review, 84(1), 37-62. 
PeEL D., Lloyd M.G., 2007, Neo-traditional planning. Towards a new ethos for land use planning? Land Use Policy 24, 393-403.

PogODZINSKY J.M., SASS T.R., 1990, The Economic Theory of Zoning: A Critical Review, Land Economics, August, 66(3), 294-314.

POGODZINSKY J.M., SASS T.R., 1991, Measuring the Effects of Municipal Zoning Regulations: A Survey, Urban Studies, 28(4), 597-621.

ROULAC S., 2007, Brand + beauty + utility = property value, Property Management, 25(5), 428-446.

RUMING K.J., 2010, Developer Typologies in Urban Renewal in Sydney: Recognising the Role of Informal Associations between Developers and Local Government, Urban Policy and Research, 28(1), 65-83.

SCOTT W.R., 1995, Institutions and Organizations, Thousand Oaks: Sage publications.

SHATKIN G., 2016, The real estate turn in policy and planning: Land monetization and the political economy of peri-urbanization in Asia, Cities, 53, 141-149.

TAYLOR Z., 2013, Rethinking planning culture: a new institutionalist approach, Town Planning Review, 84(6), 683-702.

THEURILlAT TH., RÉRAT P., CREVOISIER O., 2015, The real estate markets: Players, institutions and territories, Urban Studies, 52(8), 1414-1433.

Tiesdell S., Allmendinger P., 2005, Planning Tools and Markets: Towards an Extended Conceptualisation, In: Adams, D., Watkins, C. and White, M. (Eds.): Planning, Public Policy \& Property Markets, pp. 5676. Oxford: Blackwell Publishing.

VAN RIJ E., KORTHALS AlteS W., 2010, Looking for the optimum relationship between spatial planning and land development, Town Planning Review, 81(3), 283-301

VATN A., 2005, Institutions and the Environment, Edward Elgar, Cheltenham.

Versteeg W., HAJer M., 2010, Is This How It Is, or Is This How It Is Here? In J. Hillier and P. Healey (Eds): The Ashgate Research Companion to Planning Theory: Conceptual Challenges for Spatial Planning, Ashgate, Farnham, pp. 159-182.

WALSH E., 2017, Public versus private land controls in England and the US, International Journal of Law in the Built Environment, 9(1), 18-31.

WEBSTER CH., 2005, The New Institutional Economics and the evolution of modern urban planning: Insights, issues and lessons, Town Planning Review, 76(4), 455-502.

WeSTON R. 2003, Rhetoric: Methodology or Method? And Other Views from Heterodoxy, Comment on Focus article, Housing, Theory and Society, 20(3), 132-133. 